\title{
THE PERCEPTIONS OF MANAGEMENT ON THE BENEFITS OF ADOPTING AN ENVIRONMENTAL MANAGEMENT ACCOUNTING SYSTEM AS A WASTE MANAGEMENT TOOL
}

\author{
Mishelle DOORASAMY \\ University of Kwa-Zulu Natal, Westville, Durban South Africa \\ *e-mail: doorasamym@ukzn.ac.za
}

\begin{abstract}
The purpose of this paper is to ascertain the perception of management on the benefits of adopting an environmental management accounting (EMA) system as a waste management tool in a paper and pulp manufacturing company. This paper highlights the benefits of an EMA system and the role and importance of EMA as a decision-making tool in encouraging the adoption of cleaner production (CP) techniques and technologies. This research was based on a case study of a paper and pulp manufacturing company in KwaZulu-Natal. This research was both quantitative and qualitative in nature. Data collection instruments for the study included a Likert-type questionnaire and interviews with the environmental manager and cost accountant but the findings reported in this paper are based on the empirical evidence gathered from the questionnaire which identified that there was positive correlation between environmental performance and CP techniques and technologies. Environmental costs were hidden under general overheads and understated because the company was using a conventional costing system and not an EMA system; hence, environmental costs were not traced back to the products or processes responsible for those costs. It was evident from the qualitative data analysis that management regarded their environmental costs as too insignificant to justify implementation of an EMA system. The consequent reluctance of the company to adopt $\mathrm{CP}$ resulted in poor waste management and lower-quality environmental performance.
\end{abstract}

Keywords: environmental performance, environmental management accounting systems, cleaner production, waste management.

\section{Introduction}

In developing countries, increases in industrial activity, electricity demand, and transportation frequently result in higher levels of emissions, with poor air quality becoming a major issue (Stringer 2010, pp.34-35). Meanwhile rising costs for energy and raw material make cleaner production (CP) an increasingly significant priority, putting the focus on improved productivity and reduced environmental impact (e.g., reduced waste to landfill) achievable through improved design over the life of products, processes, and services (South Africa 2004, p.11; Lakhani 2007, p.1391).

Companies using obsolete and inefficient processes and technologies incur higher production costs that reduce profitability and competitiveness (Schaltegger, Bennett, Burritt, Jasch, 2010, pp.10-11). In the specific case of paper mills, managers often perceive investments in pollution-abatement technologies as "unproductive" because they have "no marketable and quantifiable effect in terms of productivity"
(Bras, Realff, Carmichael, 2004); potential CP opportunities are thus ignored (Baas, 2007, p.121).

Companies fail to identify the substantial savings potential and environmental benefits of $\mathrm{CP}$ when no monitoring and data collection is in place hence, the need for environmental management accounting (EMA) as an environmental and sustainability tool to collect, evaluate, and interpret the information needed to assess the potential for CP saving (with particular emphasis on non-product output costs) and to choose appropriate CP options. In practice, however, the level of implementation of EMA tends to be low because of gaps in academic knowledge of EMA and of its potential for identifying inefficiencies in a production process and for benchmarking environmental costs that would yield superior environmental and economic performance (Ferreira, Moulang, Hendro, 2010, pp.920-948; Burritt, Herzig, Tadeo. 2009, pp.431-439; Christ, Burritt, 2013, p.165; Schaltegger, et al., 2010, pp.11-15; Ván, 2012, p.3). 
Although $\mathrm{CP}$ has a proven track record, its implementation in South Africa still has some way to go. One important step that has, however, been taken in this direction is the formation of the National Cleaner Production Centre (NCPC), linked to the United Nations Industrial Development Organization (UNIDO). The NCPC-SA focus on assisting industry to implement $\mathrm{CP}$ that requires investment in cleaner technologies was confirmed at the Cleaner Production conference that took place in Gauteng in June 2013 (Delano, 2013, p.4). Integral to NCPC-SA services is resource efficiency and cleaner production (RECP), which includes energy efficiency, life cycle assessments, and environmental accounting (South African National Cleaner Production Centre, 2013).

\subsection{Significance of the study}

Waste and emissions are a sign of inefficiency in production. Waste is expensive not because of disposal fees but because of wasted material purchase value (Jasch, 2009, p.2). Although strict environmental regulations and market pressures require most companies to be ISO 14001 certified, they are often still not prepared to change production processes in a shift to CP technologies, and even when they adopt end-of-pipe technologies as part of their sustainable practices, these technologies are confined to problems arising after the production process and do not address root causes. Waste continues to accumulate in landfill sites, which merely shifts the fundamental problem. For ultimate company sustainability and eco-efficiency in production processes, CP techniques and technologies are crucial. Full compliance with ISO 14001 makes it essential for companies that seek sustainable competitive advantage through clean technologies that reduce their raw material input, thereby reducing or even eliminating waste to the ultimate benefit of their environmental and economic performance (Radonjič, Tominc, 2007, pp.1482-1493).

Why then are companies reluctant to adopt such technologies?

The likely answer is that these companies prioritize short-term profitability rather than long-term sustainability. Financial managers are reluctant to take the risk of high investment costs in environmental technology from which they anticipate no real pay- back. Accountants and financial managers, therefore, need to be made aware of the true costs - the environmental costs - associated with unsustainable production processes. Cost-reduction options do exist using existing technology, but cleaner technologies are more efficient, as they prevent emissions at source. Even so, although costly and inefficient end-of-pipe treatments such as emission-reducing dust filters that are washed out by rainwater and then disposed of in landfill merely shift the environmental problem (Jasch, 2009, p.2), it remains the case that relatively newer technologies are infrequently replaced by cleaner technologies even if they can result in improved environmental and economic performance (Schaltegger, et al., 2010, pp.144-145).

This article will add to the body of knowledge on CP and sustainable development. Managers will be able to evaluate and analyze how they can improve both their environmental and economic performance in the future and attain their sustainability targets: the so-called "triple bottom line." Improved competitive advantage will result in higher profitability, which in turn will benefit employees, managers, and other stakeholders in the company.

\subsection{Background}

The paper and pulp manufacturing process of the company on which the case study was based consumes large amounts of natural resources and also generates excessive waste. The rising costs of input resources and the increasing environmental cost has reportedly had a negative impact on the company's profitability (reported by company Cost Accountant, 2013).

Although the company has invested heavily in endof-pipe technologies and a wastewater treatment plant to reduce the environmental impact of their production processes, this has neither solved their environmental issues nor has it reduced their resource use in production. The technology used in the steam production process is outdated and obsolete, generating between 20 and 60 tons of hazardous solid waste daily in the form of unburned coal ash. In a further sign of inefficient production, the company also uses large amounts of water in their production process, resulting in high output of waste- 
water effluents (reported by company Environmental Manager, 2013).

For future sustainability and competitiveness, management needs to consider adopting $\mathrm{CP}$ techniques and technologies that will address waste issues at source. According to the $\mathrm{CP}$ philosophy, which focuses on resources and resource flows, any reduction in material and energy used will result in fewer emissions (Christ, Burritt, 2013, p.163). Because the company has hitherto used conventional accounting methods to allocate costs, management have been unaware of the true scale of their environmental costs and continue to see $\mathrm{CP}$ as an expensive strategy that requires innovation with no financial return to the company in the short term. This is a situation where EMA can systematically trace and accurately reallocate environmental costs to the relevant processes and products in a way that enables managers to identify opportunities for implementing $\mathrm{CP}$ and thereby improve environmental and economic performance. Information needed to estimate the potential for $\mathrm{CP}$ savings was obtained using material flow analysis as an EMA tool to allocate environmental and material flow costs (Jasch, 2009, p.2).

\section{Definitions and Terminology}

\subsection{Environmental Management Accounting}

EMA is a field of accounting that approaches corporate environmental information management using accounting tools and practices to support companyinternal management decision-making on environmental issues and their impact on company performance (Schaltegger, Bennett, Burritt and Jasch, 2010, p.2). Bennett, Schaltegger, and Zvezdov (2013) described EMA as a tool that tracks and traces environment-related costs that are generally hidden under overheads. It provides the information needed by managers to identify $\mathrm{CP}$ opportunities in their companies by accurately calculating and reallocating the cost to the relevant products and processes, thereby allowing identification of inefficient processes with high environmental impact.

Table 1 shows the internal calculation of environmental costs by a company.

Table 1. Environmental costs of a company

(source: Jasch, 2009)

\begin{tabular}{|l|l|}
\hline & Environmental Protection Costs (Emission Treatment and Pollution Prevention) \\
\hline+ & Costs of wasted material \\
\hline+ & Costs of wasted capital and labor \\
\hline$=$ & Total corporate environmental costs \\
\hline
\end{tabular}

Table 1 indicates that in calculating environmental costs, the purchase value of wasted material and the production costs of waste and emissions must be considered.

Ambe (2007) listed the following shortcomings of conventional management accounting practices in environmental cost consideration during internal decision-making:

- many environmental costs were "hidden" in overhead accounts,

- the allocation of environmental costs from the overhead accounts were thereafter incorrectly allocated to processes and products,
- some environmental costs were incorrectly considered "fixed" instead of "variable",

- volume and cost of wasted raw materials were incorrectly calculated,

- relevant and significant environmental costs were excluded completely from accounting records, resulting in environmental costs being understated, and

- EMA information is not considered during investment appraisal. 
In response to these shortcomings in conventional management accounting systems, and in the face of increasing environmental challenges, EMA was suggested as a business tool that would help organizations to establish better linkage between environmental and economic performance (Ambe, 2007, p.6), thus enabling businesses to achieve the triple bottom line without compromising the environment.

Godschalk (2008) noted the following internally orientated benefits to an organization of adopting EMA: assistance in achieving competitive advantage, greater cost efficiency, and improved image and customer relations. Jonäll (2008) emphasized the value of a more structured accounting system in increasing cost efficiency and improving environmental performance. Incorrect cost allocation leads to incorrect decision-making. Hence the importance, especially in strategic decision-making, of tracing cost to its actual cause, either a process or a product, rather than reflecting it under overhead accounts.

Table 2 provides a framework and guidelines on environmental cost categorization, potentially of use to companies that want to implement EMA as part of their continuous improvement policy.

Table 2. Environmental cost categories

(source: DePalma and Csutora, 2003)

\begin{tabular}{|c|c|c|c|c|c|c|c|c|c|}
\hline \multicolumn{2}{|c|}{$\begin{array}{c}1 \\
\text { Waste and emission } \\
\text { treatment }\end{array}$} & \multicolumn{2}{|c|}{$\begin{array}{c}2 \\
\text { Prevention and environ- } \\
\text { mental management }\end{array}$} & \multicolumn{2}{|c|}{$\begin{array}{c}3 \\
\text { Material purchase } \\
\text { value of non-product } \\
\text { output }\end{array}$} & \multicolumn{2}{|c|}{$\begin{array}{c}4 \\
\text { Processing cost } \\
\text { of non-product } \\
\text { output }\end{array}$} & \multicolumn{2}{|r|}{$\begin{array}{c}5 \\
\text { Environmental } \\
\text { revenues }\end{array}$} \\
\hline 1.1 & $\begin{array}{l}\text { Depreciation } \\
\text { for related } \\
\text { equipment }\end{array}$ & 2.1 & $\begin{array}{l}\text { External services } \\
\text { for environmental } \\
\text { management }\end{array}$ & 3.1 & Raw materials & 4.1 & Labor costs & 5.1 & $\begin{array}{l}\text { Subsidies, } \\
\text { awards }\end{array}$ \\
\hline 1.2 & $\begin{array}{l}\text { Maintenance } \\
\text { and operating } \\
\text { materials and } \\
\text { services }\end{array}$ & 2.2 & $\begin{array}{l}\text { Personnel for gen- } \\
\text { eral environmental } \\
\text { management activi- } \\
\text { ties }\end{array}$ & 3.2 & Packaging & 4.2 & Energy costs & 5.2 & Other earnings \\
\hline 1.3 & $\begin{array}{l}\text { Related person- } \\
\text { nel }\end{array}$ & 2.3 & $\begin{array}{l}\text { Research and De- } \\
\text { velopment }\end{array}$ & 3.3 & $\begin{array}{l}\text { Auxiliary ma- } \\
\text { terials }\end{array}$ & & & & \\
\hline 1.4 & $\begin{array}{l}\text { Fees, taxes, } \\
\text { charges }\end{array}$ & 2.4 & $\begin{array}{l}\text { Extra expenditure } \\
\text { for cleaner technol- } \\
\text { ogies }\end{array}$ & 3.4 & $\begin{array}{l}\text { Operating } \\
\text { materials }\end{array}$ & & & & \\
\hline 1.5 & $\begin{array}{l}\text { Fines and pen- } \\
\text { alties }\end{array}$ & 2.5 & $\begin{array}{l}\text { Other environmen- } \\
\text { tal management } \\
\text { costs }\end{array}$ & 3.5 & Energy & & & & \\
\hline 1.6 & $\begin{array}{l}\text { Insurance for } \\
\text { environmental } \\
\text { liabilities }\end{array}$ & & & 3.6 & Water & & & & \\
\hline 1.7 & $\begin{array}{l}\text { Provisions for } \\
\text { clean-up costs, } \\
\text { remediation }\end{array}$ & & & & & & & & \\
\hline
\end{tabular}

\subsection{Cleaner Production}

As cited in Fore and Mbohwa (2010), the United Nations Environmental Program (UNEP) describes $\mathrm{CP}$ as a "preventive, integrated strategy in which costly end-of-pipe pollution control systems are replaced by measures which reduce and avoid pollution and waste throughout the entire production cycle, through efficient use of raw materials, energy and water and emissions of any kind at the source rather than dealing with them at a later stage"; UNEP defines it further as "the continuous application of an integrated preventive environmental strategy to processes, products and services to increase overall 
effciency and reduce the risk to humans and the environment" (Fore, Mbohwa, 2010)

CP seeks to use resources more efficiently, reduce the amount of undesired outputs, and improve monetary returns by reducing material and energy consumption. Its adoption may require capital investment (Schaltegger, et al., 2010, p.7). Fig. 1 indicates the various types of environmental innovation options available for organizations; the CP model presented in this figure requires innovation to ensure sustainability of an organization.

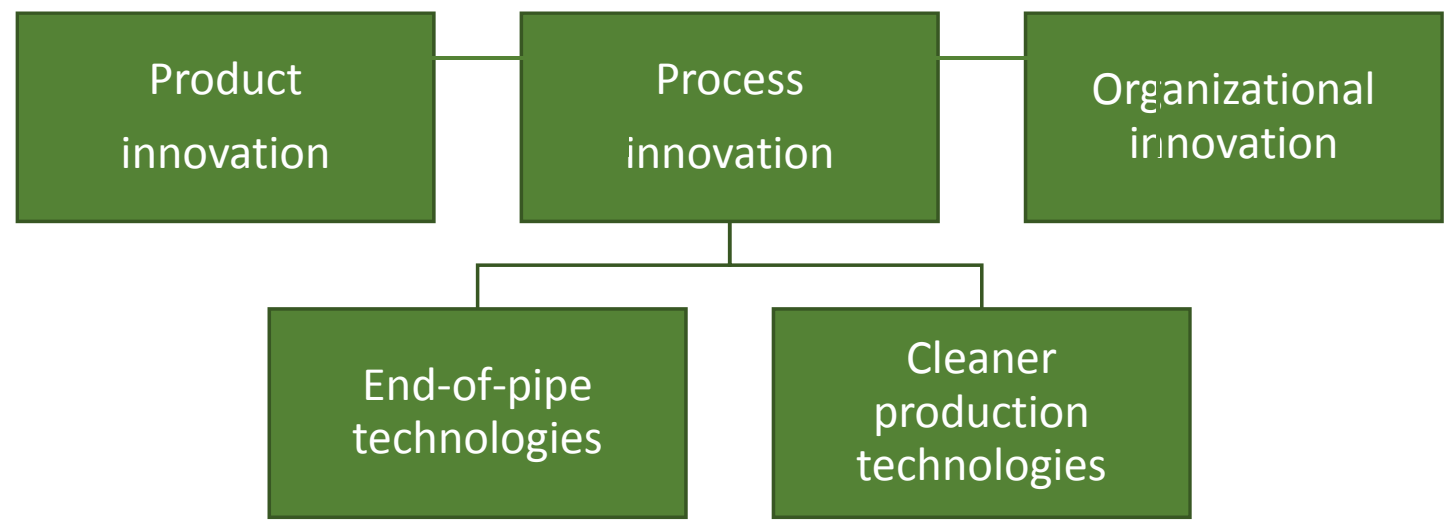

Figure 1. Types of environmental innovations (source: Frondel, et al., 2004, p.3)

\subsection{Sustainable Development in the Paper and Pulp Industry}

With global paper consumption expected to increase to more than 490 million tons per year by 2020 , there is a growing demand for raw materials by paper industries (Mousavi, et al., 2013, pp.420-424). Set against this demand, new challenges for the paper and pulp industry arising from strict environmental legislation, market pressures, and the urgent need for sustainability create strong pressure for the introduction of sustainable development in their business practices (Andrews, Pearce, 2011, pp.1446-1454; Ghorbannezhad, Azizi, Layeghi, 2008, p.1; Despeisse, Oates and Ball, 2013, pp.31-41; Liu, et al., 2013, pp.7-12; Persson, Berntsson, 2010, pp.935-943).

\subsection{Development of CP in Manufacturing Industries}

For sustainable competitive advantage, businesses need to adopt $\mathrm{CP}$ processes. Although a growing number of organizations in both manufacturing and service sectors have demonstrated the potential to successfully reduce both their operating costs and their environmental impact, the implementation of CP has in general been slow and lagging. Pilot studies by CP experts remain merely as niche examples, and decision-makers in companies fail to adopt $\mathrm{CP}$ as a corporate strategy because of shortcomings in the discrimination of information about its economic and environmental potential (Schaltegger, et al., 2010, pp.5-11).

\subsection{Role of Environmental Management Ac- counting in CP Implementation}

The United Nations Development Programme (UNDP) identifies EMA as an important management tool for business that seek to respond to environmental challenges while preserving their triple bottom line (Ambe, 2007, p.7). UNDP educates companies on the benefits of using EMA and encourages its adoption. In line with these international developments, South African companies have taken note of environmental issues in their decisions on products and processes and have identified potential savings that can be achieved when EMA is used to accurately trace and identify environmental costs (Ferreira, et al., 2010; Christ, Burritt, 2013, p.165). Ambe (2007) found that there had hitherto been a lack of awareness and understanding of the significance of the environmental costs and their impact 
on the overall performance of the organization. A number of South African companies have subsequently identified potential savings from good environmental management using EMA to accurately trace and identify environmental costs (Ambe, 2007, pp.11-12).

In a literature review by Jonäll (2008, p.2), EMA reportedly identified material purchase value of nonproduct output costs as the largest cost category. The review found that actual corporate environmental costs tended to be much higher than those disclosed by companies in their annual reports, indicating considerable potential for cost saving through strategy reconsiderations, and it showed the potential for EMA to support company decisionmaking for improved environmental performance through structured costs assessments, more effective product mixes, strategies, and investments.

A test project undertaken by Schaltegger, et al. (2010, pp.17-19) to assess the sustainable performance of companies after a combined application of EMA, cleaner production assessment (CPA), and environmental management systems (EMS) generated positive outcomes and contributed to the enhancement of CPA/EMS projects by increasing awareness of the economic implications of the environmental impact of non-product output and costs; it also provided a systematic method of controlling these costs in the short, medium, and long terms. Two of the companies involved extended the scope of their EMA to analyze other technological processes and in the process that made important decisions regarding phasing out of products and making new investments.

EMA has also helped to quantify monetary benefits of adopting alternative CP options (Ván, 2012, p.5).

\subsection{Environmental and Economic Gains from Introduction of $\mathrm{CP}$}

Cleaner technologies yield both environmental gains, in reduced pollution and reduced waste generated at the end of the production process, and financial gains, in lower maintenance costs and more efficient use of raw materials. Positive results have been recorded in all departments in the environmental management system where clean technology had been deployed (Industrial Resources Council, 2013; Ace- moglu, Akcigit, Hanley, and Kerr, 2014. p.1). The "Porter Hypothesis" postulates a win-win scenario in which well-designed environmental regulation potentially inspires innovation and strategy formulation for enhanced resource productivity that could make companies more competitive (Bras, Realff and Carmichael, 2004). Although a shift to CP processes may require investment in $\mathrm{CP}$ technologies (Christ and Burritt, 2013, p.165; Schaltegger, et al., 2010, pp.11-15), introduction of clean technology should no longer be seen exclusively as costs, as it offers a range of benefits to industries seeking to achieve sustainable development and meet the objectives of the triple bottom line (Mendes, 2012, pp.100-106; Pandey and Pandey, 2008. p.18).

The June 2013 Cleaner Production conference in Gauteng made evident the positive impact and profitability of the RECP program, showing how materials and resource efficiencies can improve competitiveness, sustainability, and profitability of local manufacturing industry (Delano, 2013, p.3).

In $\mathrm{CP}$ implementation, EMA, and in particular the EMA process of material flow analysis, is especially valuable in its provision of accurate and comprehensive information on environmental performance that makes it possible to identify potential opportunities for cost saving. Material flow cost accounting facilitates the quantification and establishment of the cost of non-product output-important information for companies making strategic decisions regarding $\mathrm{CP}$ implementation for the future.

Environmental degeneration and an increase in water and air pollution, coupled with global warming and ozone depletion, are a direct result of increased industrial production and consumption of our natural resources (Ghorbannezhad, et al., 2008, p.1). Businesses seeking to achieve sustainable competitive advantage are thus under strong pressure to introduce sustainable development in their business practices.

A study investigating the impact of ISO 14001 certification on metal and chemical manufacturing in Slovenia found that it had created better conditions for technology improvements in companies that were committed to the Integrated Pollution Prevention and Control (IPPC) directive (Radonjič, Tominc, 2007, pp.1482-1493). Companies in chemical and related industries adopted modified technologies 
to reduce their environmental impacts, while companies in metal industries used a combination of existing and new technologies after the ISO 14001 certification. The study concluded that better environmental performance was associated with greater productivity in firms that were ISO 14001 certified.

A case study on clean technologies and environmental management in a small dairy industry in Brazil found that the proposed model of environmental management for clean technologies and eco-efficient generated positive results such as generation of additional revenue from the sale of by-products that were previously considered waste (Mendes, 2012, pp.100106). Analysis of a steam generation system found that in addition to gains in the technical standards of the system and in standards of care, cleaner technologies also offered other possible gains: human gains in reduced risk of accidents, environmental gains in reduced pollution and waste, and financial gains in reduced spending on maintenance and more efficient use of raw materials. This confirms that clean technology innovations should no longer be seen only as costs, as they offer a number of benefits to industries in support of the "triple bottom line" (Mendes, 2012, pp.100-106).

\section{Research Questions and Propositions}

The study investigated the following research questions:

1) Are specific types of the major environmental costs separately identified and measured? If yes, what are they? If no, why not?

2) How are the major environmental costs, both physical and monetary, being captured (if at all) within the current accounting systems?

3) Are environmental costs regularly measured and monitored against technological standards to ensure that technology is functioning optimally?

4) Are environmental costs reflected as production costs and hidden under general overhead costs in financial statements?

5) What are the barriers to the adoption of an EMA system and to investment in CP technologies?

\section{Research Design and Methodology}

\subsection{Research Design}

A case study research methodology was followed in this study, involving quantitative data assessment and exploratory qualitative research analysis to generate theory from collected data.

According to Yin (2009), a case study is an empirical inquiry that:

- Investigates a real-life phenomenon in depth under certain contextual conditions;

- Relies on multiple sources of evidence, converging data in a triangulating manner; and

- Adopts prior theoretical propositions to guide data collection and analysis.

Zikmund (2004, p.173) noted in addition that casestudy methodology provides data for building theory that contributes to existing knowledge through analysis from another perspective.

Triangulation for the study was provided through use of a multimethod approach that incorporated both qualitative and quantitative data analysis.

\subsection{Target Population}

Although the company investigated employs approximately 300 employees, the study targeted only those involved in environmental management issues, production, operations, accounting, and cost control.

\subsection{Census Study}

As the managers were the only respondents who could provide the required data for this study, the researcher elected to conduct a census study (defined by Zikmund 2004, p. 369, as an investigation of all the individual elements that make up the population). The census included all members of the management team including top management, middlelevel managers, and frontline managers (see Table 3 for breakdown of the census population). In total, 40 questionnaires were dispatched and 37 were returned, which gave a $92.5 \%$ response rate. Zikmund (2004) stated that a sample size of 30 is adequate for obtaining valid and reliable results. 
Table 3. Composition of census population

\begin{tabular}{|c|c|c|}
\hline Department/ Level & Total Population & Sample Number \\
\hline Operations/production & 25 & 25 \\
\hline Plant foreman & 4 & 4 \\
\hline Cost accounting/control & 10 & 10 \\
\hline Environmental manager & 1 & 1 \\
\hline Total & 40 & 40 \\
\hline
\end{tabular}

\subsection{Data Collection Methods}

This research involved both quantitative and qualitative methodology. Both primary and secondary sources were used to collect information for the purpose of this study.

\subsection{Questionnaire Design}

Questionnaires used in the study consisted predominantly of Likert-scale questions, on the grounds that they simplify analysis and allow statistics to be drawn for interpretation (Zikmund, 2004, pp.330331). Questions asked during interviews were of a more complex nature, involving open-ended questions to allow respondents to speak their mind.

Reliability of outcome was assured by personal distribution and collection of questionnaires. The populations and data gathering methods used in the case study were appropriate to the phenomenon under investigation.

\subsection{Data Analysis}

The questionnaire was the primary data collection tool and was distributed to senior and middle-level managers of the company. The data collected from the responses was analyzed with SPSS version 22.0. The results have been presented as descriptive statistics in the form of graphs, cross tabulations, and other figures for the qualitative data that was collected. Inferential techniques include the use of correlations and chi-square test values, which are interpreted using the p-values.

\subsection{The Research Instrument}

The themes measured by the questionnaire for which the findings are reported in this article were corporate environmental strategy of the organization, perspectives of EMA, and barriers to the adoption of cleaner technologies.

\subsection{Reliability Statistics}

The two most important aspects of precision are reliability and validity. Reliability is computed by taking several measurements on the same subjects. A reliability coefficient of 0.70 or higher is considered as acceptable.

\section{$5 \quad$ Results and Findings}

Availability of formal accounting procedures when dealing with specific environmental issues was positively correlated (0.676) to environmental issues being incorporated into the company's strategic planning process. There was a highly positive correlation of 0.912 between allocation of environmentrelated costs to production processes and improvements to environment-related cost management.

Table 4 gives the Cronbach's alpha figures for the three themes relevant to this article.

Table 4. Cronbach's alpha figures

\begin{tabular}{|l|l|c|c|}
\cline { 3 - 4 } \multicolumn{2}{l|}{} & Number of Items & Cronbach's Alpha \\
\hline Q1 & Corporate environmental strategy of the organization & 4 of 4 & .878 \\
\hline Q2 & Perspectives of environmental management accounting & 5 of 5 & .922 \\
\hline Q3 & Barriers to adoption of cleaner technologies & 10 of 10 & .837 \\
\hline
\end{tabular}


The overall reliability score of each section exceeded the recommended value of 0.70 . This indicates a high (overall) degree of acceptable, consistent scoring for the research.

All of the themes (subsections) had values that exceed the acceptable standard.

\subsection{Factor Analysis}

Factor analysis is a statistical technique focused mainly on data reduction. A typical use of factor analysis is in survey research, where a researcher wishes to represent a number of questions with a small number of hypothetical factors. For example, as part of a national survey on political opinions, participants may answer three separate questions regarding environmental policy, reflecting issues at the local, state, and national level. Each question, by itself, would be an inadequate measure of attitude toward environmental policy, but together they may provide a better measure of the attitude. Factor analysis can be used to establish whether the three measures do, in fact, measure the same thing (Willemse, 2009).

Each matrix table is preceded by a table that reflects the results of the Kaiser-Mayer-Olkin (KMO) and Bartlett's test. The requirement is that KMO measure of sampling adequacy should be greater than 0.50, and Bartlett's test of sphericity should be less than 0.05. In all instances, the conditions were satisfied, which allow for the factor analysis procedure.

Certain components were divided into finer subcomponents, as explained in the following in the rotated component matrix.

\section{Question 1}

Table 5. KMO and Bartlett's test

\begin{tabular}{|l|c|c|}
\hline \multicolumn{2}{|l|}{ KMO measure of sampling adequacy } & .781 \\
\hline \multirow{3}{*}{ Bartlett's test of sphericity } & Approximate chi square & 78.302 \\
\cline { 2 - 3 } & $\mathrm{df}$ & 6 \\
\cline { 2 - 3 } & Significance & .000 \\
\hline
\end{tabular}

Table 6. Component Matrix

\begin{tabular}{|c|c|}
\hline & Component 1 \\
\hline $\begin{array}{l}\text { 1. Integrated environmental issues are incorporated into the company's strategic } \\
\text { planning process }\end{array}$ & .876 \\
\hline $\begin{array}{l}\text { 2. Reducing the environmental impact of products and processes forms part of the } \\
\text { total quality management (TQM) policy }\end{array}$ & .882 \\
\hline 3. Environmental objectives are linked with the company's corporate goals & .860 \\
\hline $\begin{array}{l}\text { 4. During the development of new products, environmental issues are always con- } \\
\text { sidered }\end{array}$ & .856 \\
\hline
\end{tabular}

Although all four statements were considered to be the elements of corporate environmental strategy, the response to the last two statements varied significantly as compared to the first two statements. The most important levels of agreement were for the first two statements.

The uncertainty on this question is evidenced by the large number of respondents indicating a neutral view on the last two statements, with $31.43 \%$ for statement 3 and $45.71 \%$ for statement 4 . Accord- ing to Bennett et al. (2013, pp.1-56), management commitment has a substantial influence on corporate environmental strategy and management's awareness of environmental responsibility in strategic decisionmaking has a significant bearing on how this commitment will be reflected inside and outside the organization. Lack of clear environmental goals is one of the obstacles to environmental performance measurement (Bennett, et al., 2011, pp.53-84). 
Question 2

Table 7. KMO and Bartlett's test

\begin{tabular}{|l|c|c|}
\hline \multicolumn{2}{|l|}{ KMO measure of sampling adequacy } & .781 \\
\hline \multirow{3}{*}{ Bartlett's test of sphericity } & Approximate chi square & 189.674 \\
\cline { 2 - 3 } & $\mathrm{df}$ & 10 \\
\cline { 2 - 3 } & Significance & .000 \\
\hline
\end{tabular}

Table 8. Component Matrix

\begin{tabular}{|c|c|}
\hline & Component \\
\hline $\begin{array}{l}\text { 1. Inclusion of environmental information in the present management accounting infor- } \\
\text { mation system }\end{array}$ & 900 \\
\hline $\begin{array}{l}\text { 2. Availability of formal accounting procedures when dealing with specific environmen- } \\
\text { tal issues }\end{array}$ & .952 \\
\hline $\begin{array}{l}\text { 3. Implementing cost-benefit analysis that also takes into consideration any environmen- } \\
\text { tal issues when dealing with viability of projects, course of actions }\end{array}$ & .917 \\
\hline 4. Undertaking environmental impact audits on culmination of company's activities & .748 \\
\hline 5. Reporting environmental information to external stakeholders & .906 \\
\hline $\begin{array}{l}\text { 6. Inclusion of environmental information in the present management accounting infor- } \\
\text { mation system }\end{array}$ & .900 \\
\hline
\end{tabular}

The average level of agreement is $44.00 \%$.

The level of agreement is fairly consistent except for statement 4 (74.29\%), which relates to the undertaking of environmental impact audits on culmination of company's activities.

Two of the statements show high levels of neutrality, while the remaining statements indicate higher levels of disagreement. This finding suggests that most environmental management accounting practices are not being implemented in the organization, except for environmental impact audits that are mandatory in terms of the organization's ISO 14001 accreditation. The company uses a traditional cost accounting system that does not adequately incorporate environmental information into general management accounting information. Findings in relation to Question 2, relating to environmental activities, also suggest that EMA is not being implemented by the company. Recent developments in EMA emphasize the greater need for accounting information when making decisions regarding environmental projects (Qian \& Burritt, 2008, p. 244). Previous research by Jasch and Schnitzer (2002, p. 6) showed a lack of communication between the environmental manager and cost accountant in companies.

Environmental reporting and environmental audit are based on the "stakeholder theory" that implies that a company needs to conduct their business operations in a way that is socially acceptable by the community. It can be inferred from Godschalk $(2008$, p. 250) that some firms place greater emphasis on stakeholders, as they believe that this is critical to the firm's success and will ensure future sustainability. This could explain the reason for the high level of agreement for statement 4. 


\section{Question 3}

Table 9. KMO and Bartlett's test

\begin{tabular}{|l|c|c|}
\hline \multicolumn{2}{|l|}{ KMO measure of sampling adequacy } & .758 \\
\hline \multirow{3}{*}{ Bartlett's test of sphericity } & Approximate chi square & 361.021 \\
\cline { 2 - 3 } & df & 45 \\
\cline { 2 - 3 } & Significance & .000 \\
\hline
\end{tabular}

Table 10. Rotated Component Matrix

\begin{tabular}{|r|c|c|}
\hline & \multicolumn{2}{|c|}{ Component } \\
\cline { 2 - 3 } & 1 & 2 \\
\hline 1. Relaxed regulation and law enforcement & .681 & .263 \\
\hline 2. $\begin{array}{l}\text { Integrated environmental issues are incorporated into the company's strategic } \\
\text { planning process }\end{array}$ & .876 & .610 \\
\hline 3. $\begin{array}{l}\text { Reducing the environmental impact of products and processes forms part of the } \\
\text { total quality management policy }\end{array}$ & .882 & -.313 \\
\hline 4. Environmental objectives are linked with the company's corporate goals & .860 & .117 \\
\hline 5. $\begin{array}{l}\text { During the development of new products, environmental issues are always con- } \\
\text { sidered }\end{array}$ & .856 & .198 \\
\hline 6. Difficulty in accessing information on CT & .877 & -.256 \\
\hline 7. Additional infrastructure requirements & .862 & .179 \\
\hline 8. Higher priorities to production expansion & .051 & .965 \\
\hline 9. Concern about competitiveness & -.022 & .975 \\
\hline 10. Management resistance to change & -.024 & .954 \\
\hline
\end{tabular}

Higher initial capital cost showed the highest level of agreement $(85.72 \%)$, followed by relaxed regulation and law enforcement and poor financial performance of cleaner technologies, with agreement levels of $80 \%$ and $74.28 \%$, respectively. Both limited in-plant expertise and additional infrastructure requirements showed a $68.57 \%$ level of agreement, and both the absence of incentives on economic policies and higher priorities to production expansion showed a $25.72 \%$ level of agreement. Responses relating to the last two statements (concern about competitiveness and management resistance to change) revealed higher levels of disagreement of $54.28 \%$ and $60 \%$, respectively. Research studies have identified insufficient investment capital, lack of domestic suppliers, and unsatisfactory government policies as key barriers to adoption of cleaner technologies (Liu et al. 2013), and it has also been claimed that technological barriers such as the lack of infrastructure and poor technical knowledge and capabilities affect cleaner technology adoption in developing countries. Identified barriers to cleaner technology adoption in Sri Lanka included lack of financial initiative, resource unavailability, and less stringent government regulations and policies (Fore, Mbohwa, 2010, pp.314-333).

With reference to the table for Question 3:

- The principle component analysis was used as the extraction method, and the rotation method was Varimax with Kaiser normalization. This is an orthogonal rotation method that minimizes the number of variables that have high loadings on each factor. It simplifies the interpretation of the factors.

- Factor analysis/loading showed intercorrelations between variables. 
- Items of questions that loaded similarly imply measurement along a similar factor. An examination of the content of items loading at or above 0.5 (and using the higher or highest loading in instances where items cross-loaded at greater than this value) effectively measured along the various components.

\subsection{Qualitative Findings Based on Interviews and Analysis of Company Data}

There was limited communication between the cost accountant and the environmental manager; hence, environmental issues were not accounted for during the preparation of production and profit and loss statements. Accounting failed to integrate the environmental aspects of the organization, resulting in inaccurate production costs being reported, and environmental costs were not tracked and traced back to the specific products and processes responsible for those costs. This impacted on the company's strategic decisions on the sustainability of certain processes or products. Analysis of the company's financial reports reveals that environmental costs are hidden under general overheads.

\section{Conclusion}

Differences in the level of agreement on Question 1 clearly indicates that managers had limited knowledge of the organization's corporate environmental strategy, especially in areas concerning environmental objectives and new product development. The response to Question 2 suggests that the environmental manager had limited access to actual cost accounting documents, and although the cost controller had most of the information, those concerned lacked the ability to separate the environmental element without proper guidance. EMA offers a combined approach to bridge this communication gap and enable transition of data from cost accounting and financial accounting that would potentially reduce environmental impact by increasing material efficiency. It can thus be concluded that formal and informal interactions are required between different company units that would enable the requisite sharing of environmental information to stimulate management accounting practices.
The findings on Question 3 (barriers to the adoption of cleaner technologies), which showed lack of financial resources and poor regulatory requirements, provide further evidence that $\mathrm{CP}$ remains slow and lagging in South Africa. It is strongly recommended that organizations implement EMA systems to identify their true environmental costs and allow them to do a cost-benefit analysis of investment in CP going forward. This will assist companies to achieve their sustainable development targets.

\section{$7 \quad$ Recommendations}

On the basis of the findings of this study, the following recommendation are made to management:

- The company needs to adopt an EMA system instead of a conventional costing system. This will enable managers to make informed decisions regarding future investments in $\mathrm{CP}$ techniques and technologies.

- Adopting CP techniques and technologies will result in environmental and economic benefits for the organization by reducing both input resources used in production and waste generated during production.

- The cost accountant and the environmental manager need to work together on a regular basis, which means greater involvement of accounting staff in environmental issues to ensure more accurate costing of processes and products.

\section{$8 \quad$ References}

[1] Acemoglu, D., Akcigit, U., Hanley, D. and Kerr, W., 2014. Transition to clean technology. National Bureau of Economic Research. Available at: http://www.nber.org/papers/w20743.

[2] Ambe, M.C., 2007. Environmental Management Accounting in South Africa: Status, challenges and implementation framework. D. Tech dissertation. Tshwane University of Technology.

[3] Andrews, R., Pearce, J.M., 2011. Environmental and economic assessment of a greenhouse waste heat exchange. Journal of Cleaner Production, 19, pp.1446-1454.

[4] Baas, L., 200). Integrated Environmental and Economic Performance Assessments for Strate- 
gic Planning and Policy Analysis in Paper Manufacturing. Journal of Cleaner Production, 15, pp.1205-1216.

[5] Bennett, M. Schaltegger, S., Zvezdov, D., 2013. Exploring Corporate Practices in Management Accounting for Sustainability [online], 1-56. Available at: http://www.icaew.com/academic.

[6] Bennett, M., Schaltegger, S., Zvezdov, D., 2011. Environmental management accounting [In:] M. G. Abdel-Kader (ed.), Review of Management Accounting Research, (pp.53-84) New York: Palgrave Macmillan.

[7] Bras, B., Realff, M., Carmichael, C.I., 2004. Integrated Environmental and Economic Performance Assessment for strategic Planning and Policy analysis in paper manufacturing. Final Project Report to CPBIS.

[8] Burritt, R.L., Herzig, C., Tadeo, B.D., 2009. Environmental management accounting for cleaner production: the case of a Philippine rice mill. Journal of Cleaner Production, 17 (4), pp.431-439.

[9] Christ, L. K., Burritt, R.L., 2013. Environmental management accounting: the significance of contingent variables for adoption. Journal of Cleaner Production, 41, pp.163-173 [online]. Available at:

https://www.researchgate.net/publication/27189

2767. DOI:10.1016/j.jclepro.2012.10007 (Accessed 6 April 2016).

[10] Delano, R., 2013. Valued platform to illustrate impact and profitability of RECP program. Cleaner Production Conference (online). Available at:

http://www.energyforecastonline.co.za/articles/cl eaner-production-conference (Accessed $1 \mathrm{Au}-$ gust 2013).

[11] DePalma, R., Csutora, M., 2003. Introducing Environmental Management Accounting at Enterprise Level-Methodology and Case Studies from Central and Eastern Europe. Retrieved from: http://unipub.lib.uni-corvinus.hu /223/1/ Robertacsutora.pdf (Accessed 10 February 2016).

[12] Despeisse, M., Oates, R.M., Ball, D.P., 2013. Sustainable manufacturing tactics and crossfunctional factory modelling. Journal of Cleaner Production, 42, pp.31-41, [online] Available at: http://www.sciencedirect.com/science/article/ (Accessed 21 June 2013).

[13] Ferreira, A., Moulang, C., Hendro, B., 2010. Environmental management accounting and innovation: an exploratory analysis. Accounting, Auditing \& Accountability Journal, 23 (7), pp.920-948.

[14] Fore, S., Mbohwa, G.T., 2010. Cleaner production for environmental conscious manufacturing in the foundry industry. Journal of Engineering Design Technology 8(3), pp.314-333, [online]. Available at:

http://www.emeraldinsight.com/doi/abs/10.1108/ 17260531011086180 (Accessed 6 April 2016).

[15] Frondel, M., Horbach, J., Rennings, K., 2004. End-of-Pipe or Cleaner Production? An Empirical Comparison of Environmental Innovation Decisions Across OECD Countries. ZEW Discussion papers, No. 04-82, [online] Available at: http://hdl.handle.net/10419/24090 (Accessed 9 September 2013).

[16] Ghorbannezhad, P., Azizi, M., Layeghi, M., 2009. A strategic model for cleaner production implementation in a paper making mill [in:] Proceeding of the 10th international symposium on the analytic hierarchy/network process, University of Pittsburgh, Pittsburgh. Available at: https://www.researchgate.net/profile/Payam_Gh orbannezhad/publication/228411983_A_Strategi c_Model_for_Cleaner_Production_Implementati on_In_a_Paper_Making_Mill/links/544399ea0cf 2a76a3ccc5b4f.pdf

[17] Godschalk, S., 2008. Does Corporate Environmental Accounting Make Business Sense. Ecoefficiency in Industry and Science. 24, 249-265.

[18] Industrial Resources Council, 2013. Promoting sustainable use of industrial materials. 2013. Pulp and Paper industry material [online]. Available: http://industrialresourcescouncil.org/ materials/pulpandpaperindustrymaterials/tabid /368/Default.aspx (Accessed 10 July 2013).

[19] Jasch, C., Schnitzer, H., 2002. Environmental Management Accounting. How to profit from environmental protection. EMA- environmental management accounting pilot testing. Available: http://www.ioew.at/ioew/download/ema-theoryenglish.pdf

[20] Jasch, C., 2009. Environmental and Material Flow Cost Accounting Principles and Proce- 
dures (Eco-Efficiency in Industry and Science Series, Vol 25). Dordrecht: Springer.

[21] Jonäll, P., 2008. Environmental Management Accounting (EMA), Management Accounting including Environmental Management - a literature review. Master's thesis. University of Goteborg. Available https://gupea.ub.gu.se /bitstream/2077/9542/1/07-08-31M.pdf

[22] Lakhani, M., 2007. The need for Clean Production and Product Re-design. Journal of Cleaner Production, 15 (13), pp.1391-1394.

[23] Liu, T. Z-C., Zhang, H. C., Jiang, Q.H., 2013. Environmental emissions and energy consumption assessment of a diesel engine from the lifecycle perspective. Journal of Cleaner Production, 53, pp.7-12.

[24] Mendes, L., 2012. Clean Technologies and Environmental Management: A Study on a Small Diary Industry in Brazil. Resources and Environment, 2(3), 100-106, [online]. Available at: http://journal.sapub.org/re [Accessed 5 July 2013].

[25] Mousavi, M.M.S., Hosselini, Z.S., Resalati, H., Mahdavi, S., Garmaroody, E.R., 2013. Papermaking potential of rapeseed straw, a new agricultural-based fibre source. Journal of Cleaner Production 52, pp.420-424.

[26] Pandey, A.K., 2007. Identification and Assessment of Cleaner Production technologies and appropriate technology management strategies and methods in the South African vehicle industry. Master's thesis (Technology Management). University of Pretoria.

[27] Pandey, A.K., Brent, A.C., 2008. Application of technology management strategies and methods to identify and assess cleaner production options: cases in the South African Automotive industry. South African Journal of Industrial Engineering, 19(2), pp.171-182.

[28] Persson, J., Berntsson, T., 2010. Influence of short-term variations on energy-saving opportunities in a pulp mill. Journal of Cleaner Production, 18, pp.9335-9343.

[29] Pons, M., Bikfalvi, A., Llach, J., Palcic, I., 2013. Exploring the impact of energy efficiency technologies on manufacturing firm performance. Journal of Cleaner Production, 52, pp.134-144, [online] Available at: http://elsevier.com/locate/jclepro (Accessed 1 June 2013).

[30] Qian, W., Burritt, R., 2008. The Development of Environmental Management Accounting: An Institutional View. In: S. Schaltegger, M. Bennett, R. Burritt, and C. Jasch. (eds.) Environmental Management Accounting for Cleaner Production. Springer Netherlands, pp.233-248. Available at: http://dx.doi.org/10.1007/978-14020-8913-8 12.

[31] Radonjič, G., Tominc, P., 2007. The role of environmental management system on introduction of new technologies in the metal and chemical/paper/plastics industries. Journal of Cleaner Production, 15 (15), pp.1482-1493.

[32] Schaltegger, S., Bennett, M., Burritt, R.L., Jasch, C., 2010. Eco-efficiency in industry and science. Environmental Management Accounting for Cleaner Production (5th ed.). Springer Science and Business Media. UK.

[33] South Africam, 2004. National Cleaner Production Strategy. Draft 2. Pretoria: Government printer [online] Available at:

https://www.unido.org/fileadmin/user-mediaupgrade (Accessed 6 April 2016).

[34] South African National Cleaner Production Centre, 2013. Case study in good organization management and governance practices [online]. Available at: http://unido.org/cp [Accessed 1 August 2013].

[35] Stringer, L., 2010. The Green Workplace- Sustainable strategies that benefit employees, the environment, and the bottom line. New York: Palgrave Macmillan.

[36] United Nations Industrial Development Organization, 2013. Environmental Strategies (online). Available: http://www.unido.org/en/what-wedo/environment.

[37] Ván, H., 2012. Environmental benefits and its statement in Environmental Management Accounting. Ph.D thesis. University of Szeged.

[38] Willemse, I., 2009. Statistical Methods and Calculation Skills. Cape Town: Juta \& Co.

[39] Yin, R.K., 2009. Case Study Research Design and Methods (4th ed.). London: Sage.

[40] Zikmund, G.W., 2004. Business Research Methods (7th ed.). Mason OH: Thomson SouthWestern. 